УДК 316.6:159.96:364.2

DOI:

\author{
Духневич Віталій Миколайович, \\ кандидат психологічних наук, старший науковий співробітник, \\ завідувач лабораторії психології політико-правових відносин, \\ Інститут соціальної та політичної психології НАПН України, \\ м. Київ, Україна \\ ORCID ID 0000-0003-0115-5517 \\ greyeyed76@gmail.com
}

\title{
ГОТОВНІСТЬ ГРОМАДИ ДО ВИКЛИКІВ НАДЗВИЧАЙНОЇ СИТУАЦІЇ: ПСИХОЛОГІЧНИЙ РАКУРС
}

Обгрунтовується ідея про необхідність розроблення цілісної системи забезпечення психологічної безпеки громади. Підкреслено, що діти і молодь шкільного віку - це та група населення, яка найбільше потерпає від катастрофічних подій, що зумовлено не тільки браком досвіду (знань, умінь, навичок реагування в надзвичайних ситуаціях), а й віковими особливостями їхньої психіки (низькою стресостійкістю, що призводить до виникнення стресових і постстресових розладів унаслідок нездатності опанувати стресогенну ситуацію). Обстоюється думка про можливість залучення психологів системи освіти до процесів формування безпечного середовища в громаді. Категорію «готовність колективного суб'єкта дії» визначено як: 1) сукупність якостей та знань колективних суб'єктів (груп, команд, об'єднань, державних інститутів), що дають їм змогу ефективно взаємодіяти в кризових, екстремальних чи надзвичайних умовах у процесі вирішення спільних завдань; 2) забезпечення об'єктивних умов для налагодження та підтримки конструктивної взаємодії в ситуації, що склалася. Висунуто ідею про п’ять векторів готовності: 1) спроможність відповідних державних органів та структур забезпечити необхідні умови функціонування суспільства та їхню здатність організовувати життєдіяльність громадян таким чином, щоб мінімізувати ймовірність настання надзвичайної ситуації; 2) спроможність державних структур ефективно організовувати процес підготовки до дій у разі виникнення надзвичайних ситуацій, процеси супроводження та подолання їхніх наслідків; 3) спроможність державних органів та структур забезпечити медичну, психологічну та гуманітарну допомогу постраждалим унаслідок дії надзвичайної ситуації як в умовах самої надзвичайної ситуації, так і після завершення дії деструктивних факторів; 4) спроможність суб'єктів дії виконувати свої професійні обов'язки в умовах надзвичайної ситуації; 5) спроможність суб'єктів дії в умовах надзвичайної ситуації конструктивно/ефективно вирішувати різні проблемні питання. Презентовано два виміри готовності: організаційний і психологічний; запропоновано чотири групи завдань, що потребують вирішення для психологічного забезпечення формування готовності. Розроблено систему принципів залучення фахівців-психологів різних громадських і професійних організацій громади, а також психологів системи освіти та соціальних педагогів до надання допомоги постраждалим від надзвичайної ситуації: 1) принцип партнерства, 2) принцип відкритості, 3) принцип добровільності, 4) принцип справедливої мотивації, 5) принцип необхідності приросту компетентності, 6) принцип територіальності, 7) принцип відповідальності.

Ключові слова: психологічна готовність; надзвичайна ситуація; формування готовності до надзвичайної ситуації; готовність колективного суб'єкту; принципи залучення; екстремальні умови. 


\title{
COMMUNITY READINESS FOR EMERGENCY CHALLENGES: PSYCHOLOGICAL PERSPECTIVE
}

\author{
Vitalii M. Dukhnevych, \\ Ph. D. in Psychology, Senior Researcher, \\ Head of the Laboratory of Psychology of Politico-Legal Relationships, \\ Institute for Social and Political Psychology, \\ NAES of Ukraine, Kyiv, Ukraine \\ ORCID ID 0000-0003-0115-5517 \\ greyeyed76@gmail.com
}

It is substantiated the necessity to develop a holistic system to ensure the psychological security of the community. It is emphasized that children and school youth suffer a lot from catastrophic events, that is caused not only because of lack of experience (knowledge, skills, response skills in emergencies) but also because of the age peculiarities of their psyche (low stress resistance, which leads to stress and post-stress disorders due to inability to cope with a stressful situation). It is argued that psychologists in the education system should be involved in the process of creating a safe environment in the community. The «readiness of the collective subject of action» category is defined as 1) a set of qualities and knowledge of collective subjects (groups, teams, associations, state institutions) that allow them to interact effectively in a crisis, extreme or emergency conditions in solving common problems; 2) providing objective conditions for establishing and maintaining constructive interaction in the current situation. It is shown that readiness system consists of five vectors: 1) the ability of relevant government agencies and structures to provide the necessary conditions for the society's functioning, and their ability to organize the lives of citizens in a way that minimizes the probability of emergencies; 2 ) the ability of government agencies to effectively organize the process of preparation for action in case of emergencies, the processes of monitoring and overcoming the consequences of emergencies; 3 ) the ability of state bodies and structures to provide medical, psychological and humanitarian assistance to victims of the emergency both straight in the emergency, and after the destructive factors performance; 4) the ability of the subjects to perform their professional duties in an emergency; 5) the ability of the emergency situation subjects to constructively/effectively solve various problems. There are highlighted the organizational and psychological dimensions of readiness; there are proposed four groups of tasks that should be solved to psychologically ensure the readiness formation. It is proposed the system of principles to involve psychologists who belong to various public or professional community organizations, and psychologists who work in the education system, to help victims of emergencies. Such system consists of 1) the principle of partnership, 2) the principle of openness, 3) the principle of voluntariness, 4) the principle of fair motivation, 5) the principle of the need to increase competence, 6) the principle of territoriality, 7) the principle of responsibility.

Keywords: psychological readiness; emergency situation; formation of readiness for the emergency situation; readiness of a collective subject; principles of involvement; extreme conditions.

Постановка проблеми. Проблема готовності до надзвичайних ситуацій загострюється не тільки через тривання збройного конфлікту на території країни, а й через небезпеку виникнення пов'язаних із цим надзвичайних ситуацій техногенного, медичного та соціального плану. Руйнування інфраструктурних об'єктів, збройні сутички, терористичні акти, вибухи боєприпасів, розпилення невідомих речовин, аварії на підприємствах, пожежі на сміттєзвалищах, підтоплення та знеструмлення, отруєння харчоблоків, поширення різноманітного психологічно небезпечного контенту в електронних ЗМК (зокрема різних «груп смерті» в соціальних медіа, продуктів технологій пропагандистської та інформаційної війни) тощо - це те, що першим спадає на думку, коли мова заходить про надзвичайні ситуації. А минулий рік підняв на новий рівень актуальності виклики, пов'язані з пандеміями, коли 
світом поширився раніше невідомий коронавірус SARS-CoV-2. Останній викликає атипову пневмонію COVID-19, що призвело до небачених карантинних заходів по всьому світу.

Із психологічної точки зору, справжнє лихо настає тоді, коли закінчується дія стихії чи іншого природного або неприродного лиха та починається надання допомоги постраждалим. Відомо, що не тільки самі надзвичайні ситуації, а й масштаби руйнівних дій, їхня раптовість, поширеність психологічних наслідків, до яких призводять такі ситуації, i т. ін. багато в чому зумовлюються особливостями предкатастрофного розвитку та готовністю різних інституційних суб'єктів ефективно вирішувати завдання в ситуації (В. Лебедєв, I. Малкіна-Пих, В. Рубцов, К. Сельченок, Ю. Шойгу).

Тому саме діти шкільного віку і молодь - це та група населення, яка найбільше потерпає від катастрофічних подій, що зумовлено не тільки браком досвіду (знань, умінь, навичок реагування в надзвичайних ситуаціях), а й віковими особливостями їхньої психіки (низькою стресостійкістю, що призводить до виникнення стресових і постстресових розладів унаслідок нездатності опанувати стресогенну ситуацію). Утім, негативні психологічні наслідки переживання надзвичайних, екстремальних чи катастрофічних подій спостерігаються не тільки у дітей та молоді, а й у всіх вікових груп населення України. Зокрема, спеціальної психологічної підтримки потребують ті учасники та свідки травматичних подій, для яких травматичний досвід стає перешкодою для подальшої повноцінної життєдіяльності: звільнені в запас учасники бойових дій, яким складно адаптуватися до умов мирного життя; внутрішньо переміщені особи, які не можуть інтегруватися в новому соціальному середовищі; люди, котрі через різні природні або техногенні катастрофи втратили житло чи близьких, тощо.

Природно, що проблематика упередження та подолання наслідків надзвичайної ситуації (далі - НC) постійно перебуває у фокусі профільних служб і структур. Проте події останнього часу наочно показують, що вузькопрофільні фахівці-психологи, що долучаються до подолання наслідків НС, не завжди мають змогу, а інколи й не повинні охоплювати всіх постраждалих унаслідок дії різних руйнівних факторів. Постає питання: як має бути організований психологічний супровід (у широкому розумінні) постраждалих від НС, зокрема після того, як психологи воєнізованих структур (ДСНС, поліція, ЗСУ) завершили свою роботу?

Із початком незаконної анексії Криму Російською Федерацією та у зв’язку з воєнними діями на території країни набула небаченого досі розмаху волонтерська діяльність, до якої долучилися психологи та соціальні працівники, надаючи, зокрема, відповідні фахові консультації чи підтримку постраждалим. Проте така робота не є системною і почасти має стихійний характер. Водночас особи, які пережили травматичну подію, є, крім іншого, членами певних територіальних громад i, відповідно, можуть переносити неконструктивні форми поведінки в життя після завершення безпосереднього впливу НС (зокрема на сімейні стосунки, на взаємодію з іншими людьми та соціальними інститутами тощо).

Очевидно, що психологічний супровід осіб, які постраждали внаслідок дії різних руйнівних сил, повинен мати системний характер, будуватися на відповідних ресурсах, які має не тільки держава, а й місцеві громади, та сприяти психологічній безпеці громадян. І цей супровід має координуватися та організовуватися відповідно до певних професійних стандартів надання такої психологічної допомоги.

Аналіз останніх досліджень і публікацій, виокремлення нерозв'язаних частин загальної проблеми. Як показує аналіз літератури, у наукових працях досі не склалося єдиної термінології для позначення психологічної готовності, не сформувалося одностайної думки щодо самого поняття «психологічна готовність», іiї природи та структури. Водночас надзвичайні (критичні, екстремальні, травматичні і т. ін.) ситуації та пов'язані з ними різноманітні психологічні наслідки постійно перебувають у фокусі уваги фахівців різних галузей: військових, медиків, економістів, психологів тощо. У науковій та спеціальній літературі порушуються питання підготовки фахівців до діяльності в екстремальних ситуаціях (Н. Іванова, Я. Когут, І. Малкіна-Пих, О. Самойлик, Р. Терьохін та ін.), організації 
та забезпечення діяльності відповідних служб у разі настання НС (М. Корольчук, В. Розов, О. Колесніченко та ін.), психологічних наслідків переживання особистістю травматичних подій (В. Горбунова, І. Губеладзе, І. Малкіна-Пих, Т. Титаренко та ін.) тощо.

Проте попри значний інтерес науковців та практиків потребує уточнення сама категорія готовності в ракурсі індивідуальних та колективних суб’'єктів, нагальним видається і розроблення засад формування такої готовності.

Мета статті полягає в означенні ключових векторів готовності громади до викликів надзвичайної ситуації, а також у визначенні завдань формування такої готовності та принципів залучення можливих учасників надання допомоги постраждалим унаслідок НС.

Виклад основного матеріалу дослідження. Із психологічної точки зору ситуація $€$ відкритою системою, оскільки на неї впливають щонайменше два системних утворення: сама особистість у своїй неповторності та сукупність факторів психологічного середовища. Фактори непсихологічного середовища (предметний і соціальний світи), як справедливо зауважив К. Левін, можуть вплинути на людину лише в тому випадку, якщо вони стали фактами психологічного середовища (Левин, 2000). Особистість, як суб'єкт власного життя та системи об'єктивних відносин предметного та соціального світу, залежно від наявних та актуальних потреб і цілей та їх поєднання визначає конфігурацію і зміст (якісне наповнення) психологічних ситуацій. Інакше кажучи, будь-яка ситуація стає психологічною і може оцінюватися людиною як надзвичайна, екстремальна чи критична, коли іiі вплив на внутрішню картину світу людини актуалізує відповідні комплекси потреб, оцінок, ставлень, настановлень і т. ін. та ситуація презентується у свідомості особи як певна подія.

Подія завжди наділена особистісним смислом - поза особистістю не може бути події. Саме тлумачення надзвичайної (критичної, екстремальної) ситуації як події ${ }^{1}$ означає, що відбулося вбудовування актуальної ситуації у внутрішню картину світу особистості. Після цього особистість співвідносить себе з об'єктивними умовами дійсності, визначає свій локус (власне місце в системі зв'язків та відносин-ставлень-стосунків) у ситуації та, відповідно, ідентифікує себе як ініціатора, жертву або очевидця.

Російська дослідниця О. Рягузова (2008) в одній із своїх публікацій зазначає, що психологічна ситуація містить у собі репертуар способів дій, та посилається на ідеї Альфреда Шютца про те, що перед тим як людина робить якусь дію, вона повинна бачити цю дію закінченою, тобто «дія є здійснення передбачуваного майбутнього» (Шютц, 2003). 3 огляду на це дослідниця виділяє «дієвий план психологічної ситуації» (функціональне і ціннісне осмислення, схема дії, які репрезентують у найбільш загальних рисах модус поведінки в певному класі ситуацій). Якщо людина ідентифікує ситуацію як типову, у неї актуалізується звичний «дієвий план», орієнтований на збереження (якщо ситуація позитивна) або зміну ситуації (якщо ситуація оцінюється як негативна). Якщо ж ситуація є нетиповою і немає звичних, стереотипних програм дій (тобто немає «дієвого плану»), у людини актуалізуються різноманітні психологічні стани та процеси, орієнтовані на відновлення рівноваги. I часто в напружених, високостресогенних ситуаціях таких ресурсів людині може бракувати.

Отже, можна говорити про те, що в надзвичайних (екстремальних, критичних) ситуаціях, коли у людини немає звичного «дієвого плану», нагальною є потреба у фахівцях та командах, підготовлених до дій у ситуаціях, що характеризуються високим рівнем невизначеності та стресовості. Частково таке завдання вирішується шляхом підготовки відповідних фахівців ДСНС та інших спеціальних воєнізованих підрозділів і структур. Але тільки частково, адже саме члени громади, а також ті, хто опинився в зоні лиха, стають тими безпосередніми учасниками подій, що своїми діями або бездіяльністю можуть вплинути на розгортання ситуації. Тому образ можливого «дієвого плану» можна формувати як на рівні конкретної особи, так і на рівні різних колективних суб’єктів (груп, громад, спільнот) та закладати основи готовності до НС.

\footnotetext{
${ }^{1}$ У широкому значенні під подією розуміють те, що відбулося, те чи інше значне явище, тобто йдеться про факт суспільного або особистого життя.
} 
Уперше поняття «готовність»у радянську психологічну науку увів Л. Виготський, який розглядав його крізь призму готовності дітей до школи. Науковець також запропонував відому тезу про зону найближчого розвитку, яку активно відтак розробляли О. Лурія та інші науковці. Зона найближчого розвитку - рівень розвитку, досягнутий дитиною в процесі іiі взаємодії з дорослим, який формується в особистості під час спільної з ним діяльності, але не проявляється в індивідуальній діяльності. Проте ця категорія може бути застосована не лише до дитини, а й до дорослого, на чому, власне кажучи, будуються психологічні тренінги. У контексті нашої проблематики це означає, що готовність може формуватися відповідно до певних правил та для вирішення тих чи інших завдань.

Наявні дослідження формування готовності здебільшого стосуються окремих іiі різновидів: готовність до шкільного навчання, готовність до вивчення нового матеріалу, готовність особистості до трудової діяльності, готовність до виконання бойового завдання, готовність до дослідження педагогічного середовища, готовність до інноваційної діяльності, готовність до політичного вибору тощо.

Готовність до НС у спеціальній літературі часто розглядають як варіант готовності до дії або до діяльності в певних умовах. Готовність до дії найбільш грунтовно була досліджена в межах інженерної психології. По-перше, це наявність в оператора необхідних для успішного виконання дій знань, умінь і навичок. По-друге, готовність до термінової реалізації підготовленого алгоритму дії у відповідь на появу конкретного сигналу. По-третє, здатність прийняти рішення для здійснення якоїсь дії. М. Колосов (2009) визначає готовність до дії як стан мобілізації всіх психофізіологічних систем людини, які гарантують якісне виконання конкретних дій.

Готовність особистості до певного виду діяльності - це обгрунтований певним видом діяльності комплекс якостей, станів і відносин, знань, практичних умінь i навичок, необхідних для досягнення соціально значущих цілей і результатів. Психологічна готовність до діяльності містить у собі не тільки настановлення (як усвідомлені, так і неусвідомлені) на певні форми реагування, але також моделі найбільш імовірної поведінки, усвідомлення завдання, виділення оптимальних способів дій, оцінку свого потенціалу відповідно до майбутніх вимог і необхідності досягнення певного результату (Дьяченко, \& Кандыбович, 1986).

Загалом, ми вважаємо, що спроможність опанувати надзвичайну ситуацію чи готовність до ефективного реагування на таку ситуацію має декілька векторів:

1) спроможність відповідних державних органів і структур забезпечити необхідні умови функціонування суспільства та організувати життєдіяльність громадян таким чином, щоб мінімізувати ймовірність виникнення НС. Це передбачає, зокрема, постійне визначення та моніторинг ризиків природного, техногенного та соціального плану, а також слабких сторін забезпечення нормальних умов життя;

2) спроможність відповідних державних структур ефективно організовувати процес підготовки до дій у разі виникнення надзвичайних ситуацій, супроводження та подолання наслідків надзвичайних ситуацій. Серед іншого йдеться також про управління процесами мотивації різних індивідуальних та колективних суб'єктів до розвитку власних компетентностей, які можуть бути затребуваними в разі настання НC;

3) спроможність відповідних державних органів та структур забезпечити медичну, психологічну та гуманітарну допомогу постраждалим унаслідок дії надзвичайної ситуації як в умовах самої надзвичайної ситуації, так і після завершення дії деструктивних факторів;

4) спроможність суб’єктів дії виконувати свої професійні обов'язки задля надання допомоги громадянам, що переживають надзвичайну чи екстремальну ситуацію або подію. Під суб'єктами дії ми розуміємо фахівців, що в актуальних умовах продовжують виконувати свою професійну діяльність, пов'язану із впливом на інших людей (наприклад, медики, фахівці ДСНС, психологи, поліцейські тощо);

5) спроможність суб'єктів дії в умовах надзвичайної ситуації конструктивно/ефективно вирішувати різні проблемні питання. Серед іншого це передбачає 
належну організацію та управління інформаційними потоками і каналами, а також ефективну координацію дій різних суб’єктів.

Поєднання означених векторів створює умови для формування готовності індивідуальних та колективних суб'єктів діяти і виконувати поставлені завдання. Таким чином, ми можемо в першому наближенні операціоналізувати категорію готовності індивідуальних та колективних суб'єктів до дій в умовах надзвичайної ситуації.

Під готовністю індивідуального суб'єкта (діï) до надзвичайної ситуачії слід розуміти сукупність якостей, знань, навичок, мотивів особистості, які забезпечують конструктивне/ефективне виконання професійних завдань у межах запропонованих задач, а також сукупність об’єктивних умов діяти (відповідні ситуації, можливості виконувати професійні завдання тощо).

3 позиції індивідуального суб’єкта дії готовність до надзвичайної ситуації являє собою ставлення особистості до різних ситуативних змін, що виявляється в її здатності брати до уваги об'єктивні зміни обстановки й адекватно реагувати на них, спираючись на отриманий раніше досвід, й опановувати при цьому свої особисті бажання та емоційні реакції. Основними соціально-психологічними детермінантами, які зумовлюють психологічну готовність індивідуального суб'єкта до надзвичайної ситуації, є цінності, соціально-психологічні настановлення та відповідальність.

Готовність колективного суб'єкта дії - не прямий наслідок, не механічна сума готовностей індивідів, що утворюють такий колективний суб'єкт. Часто, окрім мобілізації індивідуальних якостей, потрібно залучити до вирішення актуальних завдань суспільну думку, традиції, створити спільне настановлення і колективний настрій на досягнення бажаного образу перспективного майбутнього (наприклад, подолання наслідків НС). Загальний успіх $є$ результатом не окремо взятих індивідуальних дій, а спільних, узгоджених зусиль багатьох людей. Колективний результат базується на правильному сприйнятті та уявленні всіх учасників процесу вирішення завдання, взаєморозумінні, взаємовпевненості, взаємній довірі, згуртованості, навичках взаємодії. Відповідно, зміст та структура готовності колективного суб'єкта розкриваються у спільній цілеспрямованості, направленості когнітивних, емотивних та волятивних проявів майстерності та настановлень на чітке виконання завдання.

Отже, під готовністю колективного суб'єкта (дії) до надзвичайної ситуаиії слід розуміти 1) сукупність якостей та знань колективних суб'єктів (груп, команд, об'єднань, державних інститутів), що дають їм змогу ефективно взаємодіяти в кризових, екстремальних чи надзвичайних умовах у процесі вирішення спільних завдань; 2) забезпечення об'єктивних умов для налагодження та підтримки конструктивної взаємодії в ситуації, що склалася.

Першими на місце подій, коли трапилося якесь лихо, завжди прибувають члени місцевої громади. Ось чому формування готовності до НС має відбуватися саме на рівні конкретної громади: саме члени громади і громада як суб'єкт, а ніхто інший, можуть статти тим експертним середовищем, що дасть змогу швидко визначити наявні ризики, ресурси та можливості в опануванні можливої НС. Готовність не можна сформувати чи насадити ззовні. Тому процес підготовки чи моделювання ситуацій має виходити саме 3 потреб членів громади як суб’єктів, що запотребують імовірно, такої допомоги.

Саме на рівні громади мають бути створені і напрацьовані механізми залучення та підготовки фахівців, що можуть долучатися до організаційної, матеріальної, медичної, гуманітарної та психологічної допомоги постраждалим унаслідок дії руйнівних факторів чи сил. На нашу думку, психологічними ресурсами тут можуть стати різноманітні громадські професійні об'єднання, а також осередки Психологічної служби системи освіти, що функціонують у межах ОТГ. Останню віднесено сюди, оскільки в Положенні про психологічну службу в системі освіти України в п. 1.3 зазначено: «Метою діяльності психологічної служби є сприяння створенню умов для соціального та інтелектуального розвитку здобувачів освіти, охорони психічного здоров'я, надання психологічної та соиіально-педагогічної підтримки всім учасникам освітнього процесу відповідно до цілей та 
завдань системи освіти» (виділення наше. - Авт.) (Наказ Міністерства..., 2018). Інакше кажучи, фахівці-психологи та соціальні педагоги, за їхньої добровільної згоди та за умови дотримання певних організаційних вимог, можуть бути ресурсом громади у вирішенні завдань формування готовності громади до НС.

Аналіз літератури засвідчив, що готовність до НС має щонайменше два виміри: організаційний і психологічний. Організаційний вимір готовності передбачає перш за все планування: 1) управління людськими та 2) фінансовими ресурсами; 3) наявність запасів на випадок НC і 4) порядок здійснення зв'язку та обміну інформацією. Таке планування дає змогу пом'якшити руйнівну дію лиха завдяки наданню своєчасної та ефективної гуманітарної, медичної та психологічної допомоги тим, хто найбільше іiї потребує. У цьому випадку працює формула: «час, витрачений на планування надання допомоги в разі НС, відповідає часу, заощадженому в разі настання $\mathrm{HC».}$

Всесвітня організація охорони здоров'я рекомендує розглядати планування на чотирьох рівнях: 1) інституційного планування надання допомоги $\mathrm{HC}, 2$ ) планування надання допомоги в разі НC, 3) планування дій у надзвичайних обставинах та 4) стандартних оперативних процедур.

Розгляньмо ці етапи більш детально.

1. Інституційне планування надання допомоги при НС визначає загальні рамки, в яких будуть здійснюватися дії гуманітарного спрямування.

2. Планування надання допомоги в разі НС передбачає виявлення, консолідацію та організацію ресурсів і можливостей, щоб досягти рівня готовності, необхідного для своєчасного та ефективного реагування на потенційну загрозу НС. Це: визначення функцій та обов'язків, вироблення політики і процедур, а також вибір і розроблення універсальних інструментів для реагування (наприклад, використання національних груп 3 надання допомоги в разі НС, системи управління інформацією і т. ін.). Із психологічної точки зору це формування образу дій у ситуації, що базується на припущеннях щодо ризиків і небезпек. Такі образи не є деталізованими, оскільки не містять сценаріїв конкретних стихійних лих.

3. Планування дій у надзвичайних обставинах полягає в розробленні планів, які грунтуються на конкретних небезпечних явищах або відомих чинниках ризику на місцевому, національному, регіональному і навіть глобальному рівнях (наприклад, землетрус, повінь або спалах захворювань) та визначають процедури дій щодо реагування на них, засновані на передбаченні необхідних ресурсів і можливостей.

4. Стандартні оперативні процедури (СОП) - це набір стандартних процедур, які «вводять у дію» плани надання допомоги в разі НC, і дій у надзвичайних обставинах. Іншими словами, СОП точно визначають те, як окремі особи або підрозділи виконуватимуть свої функції згідно з планом (наприклад, сповіщення про тривогу і мобілізація груп та команд 3 надання допомоги в разі НС, дислокація цих груп за оцінкою ситуації тощо). СОП описують, власне, що має бути зроблено, як це має бути зроблено, хто несе відповідальність за виконання тієї чи іншої дії, і точно визначає наявні ресурси (Руководство ..., 2007).

Адаптуючи ці положення до завдань нашого дослідження, можемо констатувати, що психологічний вимір готовності передбачає вирішення декількох груп завдань:

1) визначення умов залучення психологів громадських та професійних об'єднань, а також психологів системи освіти до дій 3 надання допомоги постраждалим унаслідок деструктивної дії НС. Зокрема, це передбачає: а) визначення принципів, правил та процедур взаємодії психологів ДСНС та фахівців-психологів, соціальних педагогів під час роботи 3 постраждалими внаслідок НС; б) розроблення та впровадження системи заохочень для фахівців-психологів та соціальних педагогів, які будуть залучатися (добиратися) до процесу підготовки та подальшого формування відповідних команд на рівні об'єднаних територіальних громад;

2) розроблення організаційних і методичних засад та створення системи підготовки психологів i соціальних педагогів, що можуть залучатися до надання допомоги постраждалим від НС. Серед іншого це передбачає визначення профілю необхідних компетентностей та добір відповідних засобів (технік) підготовки; 
3) добір членів і формування мобільних груп реагування з числа фахівців-психологів, що можуть разом із психологічною службою ДСНС надавати допомогу в разі НС; підготовка відповідних команд;

4) розроблення спільно із психологічною службою системи ДСНС рекомендацій, інструкцій та практичних порадників для фахівців-психологів і соціальних працівників щодо інформаційного та психологічного супроводу громадян у разі виникнення НС, психологічного супроводу громадян після пережитої НС тощо.

В основу залучення фахівців-психологів різних громадських чи професійних організацій громади (ОТГ), а також психологів системи освіти та соціальних педагогів до надання допомоги постраждалим від НС можуть бути покладені такі принципи:

1) принции партнерства - грунтується на взаємній відповідальності, згоді та спільності інтересів. Цей принцип передбачає спільну відповідальність представників державних органів і структур та фахівців-психологів за творення психологічно комфортного та безпечного життя в громаді. Дія цього принципу базується також на взаємному інформуванні представників влади та психологів системи освіти про осіб, що потребують спеціальної психологічної допомоги, оскільки їхній травматичний досвід стає перешкодою для повноцінної життєдіяльності та може впливати на безпеку громади чи окремих іiї членів (дітей, інших громадян, громади в цілому);

2) принщии відкритості - полягає в тому, що профільні фахівці, які мають відповідну підготовку, можуть включатися до складу команд та груп, які в разі настання НС можуть бути залучені до подолання iї наслідків. Таке залучення має відбуватися 3 дотриманням відкритих, зрозумілих та єдиних для всіх правил та умов. Дія цього принципу передбачає також інформування громади про наявність таких команд i груп, а також окремих підготовлених фахівців, до яких можуть звертатися по допомогу люди, що пережили дію травматичних факторів НС (це можуть бути телефони довіри, кабінети психолога на базі освітнього чи громадського закладу тощо);

3) приничип добровільності - передбачає добровільну участь фахівців психологічного профілю в програмі профільної підготовки;

4) принц̧ип справедливої мотивації - полягає в тому, що особи, які успішно завершили навчання та дали згоду на своє залучення до груп і команд, котрі можуть мобілізовуватися в разі настання НС, мають право розраховувати на компенсацію. Якщо це буде передбачено, витрати на супровід постраждалих від НС також може взяти на себе ОТГ або/та держава. Це вимагатиме застосування диференційованого підходу та розроблення «мотиваційного меню», у якому такі фахівці можуть обрати найбільш привабливий для себе варіант відшкодування (наприклад, грошова компенсація, декілька днів додатково оплачуваної відпустки, податкове послаблення тощо). (Зрозуміло, розроблення такого меню вимагатиме ретельної підготовки та узгодження відповідних рекомендацій з органами державної влади). Зазначимо також, що без урахування цього принципу навряд чи завдання формування готовності можуть вирішуватися ефективно, адже, як відомо, альтруїстична мотивація спрацьовує далеко не завжди;

5) принцุип необхідності приросту компетентності - передбачає, що для того, аби бути спроможним допомогти іншому в умовах надзвичайної (критичної, екстремальної) ситуації або після завершення дії руйнівних факторів, фахівці мають пройти обов'язкову підготовку та періодично підвищувати свій фаховий рівень;

6) принциип територіальності - полягає в тому, що фахівці, які пройдуть відповідну підготовку, мають бути готовими за потреби (наприклад, у разі настання НС) надавати свої послуги на території всієї ОТГ, а не лише окремого населеного пункту. Якщо організаторами дій з ліквідації наслідків НС буде ухвалено відповідне рішення, останні повинні взяти на себе необхідні видатки щодо організаційного забезпечення діяльності таких фахівців;

7) принциип відповідальності - означає готовність фахівців, що виявили бажання пройти відповідну підготовку та долучатися до відповідних заходів (підготовки та перепідготовки, а за потреби - до роботи з особами, що зазнали дії НС), брати на себе певні 
професійні та етичні зобов'язання за якість роботи чи послуг, що вони можуть надавати членам громади.

Висновки та перспективи подальших досліджень. Отже, маємо підстави вважати, що мета виконаної наукової роботи загалом досягнута, а відтак запропоноване бачення блоків завдань із формування готовності та принципів залучення фахівців-психологів до надання допомоги постраждалим від НС може бути використане в подальших теоретичних та практичних розробках проблематики психологічної безпеки громади.

Перспективу соціально-психологічних досліджень з означеної тематики вбачаємо в подальшій конкретизації засадничих положень формування готовності суб'єктів дії до надзвичайної ситуації, а також у розробленні та апробації відповідних програм залучення і підготовки психологів на рівні окремих ОТГ до забезпечення психологічної безпеки іiі членів, а також у подальших прикладних соціально-психологічних дослідженнях процесів формування та розвитку безпечного середовища.

\section{Список використаних джерел}

Дьяченко, М. И, \& Кандыбович, Л. А. (1986). Психологическая готовность. Москва: Наука.

Колосов, М.Б. (2009). Готовность $\kappa$ деятельности в психологии. Взято из http://www.psychology-online.net/articles/doc-1408.html.

Левин, К. (2000). Теория поля в сочиальных науках. Санкт-Петербург: Речь.

Наказ Міністерства освіти і науки України № 509 від 22.05.2018 «Про затвердження Положення про психологічну службу у системі освіти України». Взято 3 https://zakon.rada.gov.ua/laws/show/z0885-18\#n19.

Руководство по планированию оказания помощи при ЧС и действий в чрезвычайных обстоятельствах (2007). Взято из https://www.refworld.org.ru/pdfid/54c2146d4.pdf.

Рягузова, Е. В. (2008). Психологическая ситуация как предмет теоретической рефлексии. В Проблемы соџиальной психологии личности (с. 89-97). Саратов: Саратовский государственный университет. Взято из http://psyjournals.ru/sgu_socialpsy/issue/index.shtml.

Шютц, А. (2003). Смысловая структура повседневного мира: очерки по феноменологической социологии. Москва: Институт Фонда «Общественное мнение».

\section{References}

Dyachenko, M. I., \& Kandybovich, L. A. (1986). Psikhologicheskaya gotovnost [Psychological readiness]. Moscow: Nauka. (in Russian)

Kolosov, M. B. (2009). Gotovnost $k$ deyatelnosti $v$ psikhologii [Readiness for activity in psychology]. Retrieved from http://www.psychology-online.net/articles/doc-1408.html. (in Russian)

Levin, K. (2000). Teoriya polya $v$ sotsialnykh naukakh [Field theory in the social sciences]. St. Petersburg: Rech. (in Russian)

Nakaz Ministerstva osvity i nauky Ukrainy № 509 vid 22.05.2018 «Pro zatverdzhennia Polozhennia pro psykholohichnu sluzhbu u systemi osvity Ukrainy» [Order of the Ministry of Education and Science of Ukraine № 509 of 22.05.2018 «On approval of the Regulations on psychological services in the education system of Ukraine»]. Retrieved from https://zakon.rada.gov.ua/laws/show/z0885-18\#n19. (in Ukrainian)

Rukovodstvo po planirovaniyu okazaniya pomoshchi pri ChS i deystviy $\mathrm{v}$ chrezvychaynykh obstoyatelstvakh [Planning Guide to help in emergencies, and contingency plans]. (2007). Retrieved from https://www.refworld.org.ru/pdfid/54c2146d4.pdf. (in Russian)

Ryaguzova, E. V. (2008). Psikhologicheskaya situatsiya kak predmet teoreticheskoy refleksii [Psychological situation as a subject of theoretical reflection]. In Problemy sotsialnoy psikhologii lichnosti [Problems of social psychology of personality] (pp. 89-97). Saratov: Saratovskiy gosudarstvennyy universitet. Retrieved from http://psyjournals.ru/sgu_socialpsy/issue/index.shtml. (in Russian)

Shutz, A. (2003) Smyslovaya struktura povsednevnogo mira: ocherki po fenomenologicheskoy sotsiologii [The semantic structure of the everyday world: essays on phenomenological sociology]. Moscow: Institut Fonda «Obshchestvennoye mneniye». (in Russian) 